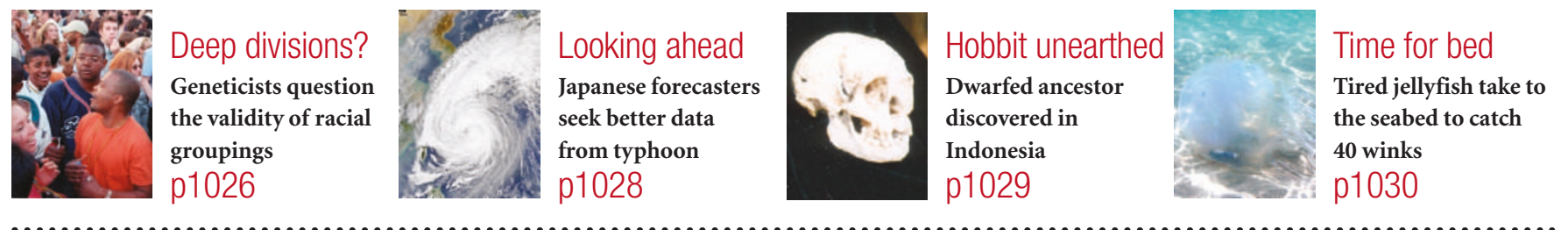

\title{
Science shares the limelight as election battle enters final phase
}

Erika Check and Geoff Brumfiel, Washington

This year's epic battle to secure the White House has bitterly divided America. But as the final showdown on 2 November nears, observers agree on one thing: science has for once played a prominent role in the contest.

Several key research issues found their way into speeches and news headlines during the campaign, including stem-cell research, nuclear-weapons proliferation, nuclear waste and the alleged politicization of scientific decisions under George W. Bush's administration.

But the topic that grabbed the nation's attention as the campaign reached its frenetic peak in October was the shortage of flu vaccines - an issue especially important to older Americans, the nation's most reliable voters.

The shortage made the news on 5 October, when California-based Chiron announced that some 48 million doses of flu vaccine made in Britain would be lost because of manufacturing problems. The shortfall was raised in the third and final presidential debate on 13 October, when Bush said he hoped that Canada could help replace the lost doses, but added "if you're younger, don't get a flu shot this year”. Presidential challenger John Kerry made the most of the problem, alleging that Bush's healthcare plan for America was "don't get sick".

The candidates traded daily attacks on the issue for the best part of a week, with Bush claiming that it showed how lawsuits have scared vaccine makers out of the market. Kerry countered that the shortage revealed the damage done by Bush to the US healthcare system.

The United States has already seen two shortages of flu vaccine in the past four years, and numerous reports have warned that the country's vaccine manufacturing and distribution systems need a major overhaul. Whether that will now happen remains unclear. "The plus is that the issue will get publicized some more," says Frank Sloan, an economist at Duke University in Durham, North Carolina, who chaired a 2003 Institute of Medicine report on vaccine financing. But he adds that nothing he has heard from the candidates convinces him that either has a firm grip on how to fix the problem.

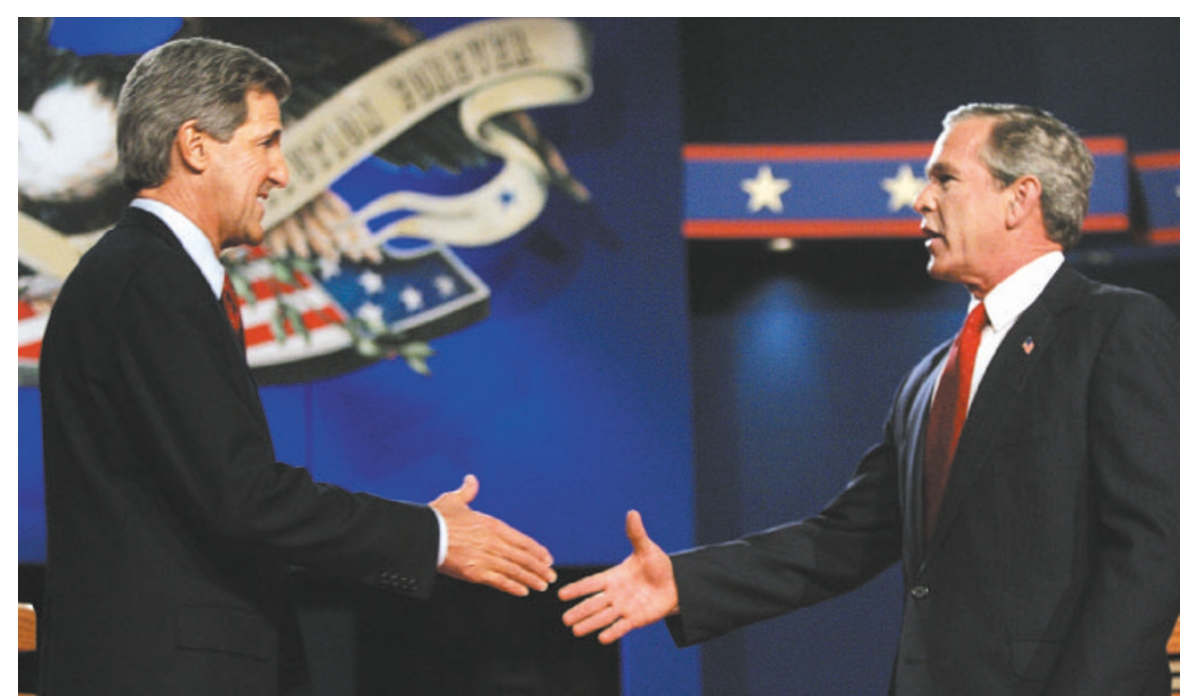

The third presidential debate saw George Bush (right) and John Kerry clash over flu vaccines.

Stem-cell research has also held a prominent position in the campaign, especially after the death of the actor and research advocate Christopher Reeve on 10 October. Kerry has pledged to overturn Bush's 2001 decision to limit federal funding for stem-cell research. His campaign staff believe that this has helped Kerry to make inroads with undecided voters who have relatives with diseases that might be treated as a result of stem-cell research.

\section{Broader critique}

Kerry has tried to broaden the stem-cell issue into a wider critique that Bush ignores scientific advice when setting national policy. "By blocking stem-cell research, President Bush has sacrificed science to ideology," Kerry told a crowd at Ohio State University in Columbus on 21 October - a message that has been amplified by a group of scientists travelling the country and delivering speeches detailing Bush's alleged abuses of science.

Physics-related issues have also made their mark. Nuclear non-proliferation took an unexpectedly prominent role in the first presidential debate on 30 September, when Kerry and Bush both identified it as their top priority in foreign policy. And the pair continued to clash over plans for a nuclear-waste dump which Bush supports and Kerry opposes - at
Yucca Mountain in Nevada, one of the most keenly contested states in the election.

But the prominence of such issues won't necessarily help science, some observers say. They contend that scientists' backing for fewer restrictions on stem-cell research and for California's Proposition 71, which would spend $\$ 3$ billion on the field in that state, might send the message that the scientific community has a political agenda of its own.

"I think ultimately it's really bad for science," says Daniel Sarewitz, a science-policy analyst at Arizona State University in Tempe. "It introduces science as legitimately politicized by the scientific community." That could make it more difficult to argue that science should be allowed to operate without political interference, he says.

Henry Kelly, president of the Federation of American Scientists in Washington DC, and an adviser on scientific issues to Kerry's team, welcomes the involvement of scientists in this year's campaign. "If any citizen has something to contribute to the debate, they should be encouraged to step up," he says.

But John Marburger, Bush's science adviser, thinks that political action by researchers could erode bipartisan support for science. "I don't think there's any doubt that it's created a negative atmosphere for science," he says. 